\title{
Determination of Radiosurgery Treatment Volume for Intracranial Germ Cell Tumors (GCTS)
}

\author{
Murat Beyzadeoglu, Ferrat Dincoglan, Omer Sager*, Selcuk Demiral \\ Department of Radiation Oncology; University of Health Sciences, \\ Gulhane Medical Faculty, Ankara, Turkey \\ *Corresponding author's email: omersager [AT] gmail.com
}

\begin{abstract}
----
Background: Radiation therapy (RT) volumes for intracranial germ cell tumors (GCTs) may include focal treatment volumes, whole ventricle irradiation, whole brain irradiation, or irradiation of the entire neuroaxis. $R T$ doses and volumes for management of primary intracranial GCTs have been an area of active research over the years. Improved sparing of critical organs by use of less extensive RT volumes and lower doses has been investigated for avoiding excessive morbidity of treatment. Herein, we assess intracranial GCT treatment volume determination.

Methods: Treatment volume definition for intracranial GCT by incorporation of Magnetic Resonance Imaging (MRI) was comparatively assessed in our study. Reference volume for comparison purposes was defined after thorough assessment and collaboration of the board certified radiation oncologists. Definition of radiosurgery target volume was based solely on CT images or fusion of CT with MRI. Comparative evaluation of treatment volume determination was performed.

Results: Ground truth target volume defined after thorough evaluation and collaboration of the board certified radiation oncologists was similar with treatment volume definition based on CT-MR fusion based imaging.

Conclusions: In conclusion, radiosurgery treatment planning for intracranial GCTs may be improved by incorporation of MRI into target definition process. Clearly, further studies are warranted to draw firm conclusions on optimal target definition for intracranial GCT radiosurgery.
\end{abstract}

Keywords---- germ cell tumor (GCT), stereotactic radiosurgery (SRS), target volume, magnetic resonance imaging (MRI)

\section{INTRODUCTION}

Primary intracranial germ cell tumors (GCTs) comprise a heterogeneous group of tumors accounting for less than $5 \%$ of all central nervous system (CNS) tumors in Western countries, but the incidence is typically higher in the Eastern regions of Asia [1-3]. Most common location for primary intracranial GCTs is the midline region of the brain around the third ventricle, with the majority of lesions occurring in the suprasellar cistern, pineal gland, and neurohypophseal area. Other locations for primary intracranial GCTs include the basal ganglia, thalamic nuclei, and floor of fourth ventricle. There is male preponderance for primary intracranial GCTs.

Primary therapeutic options for primary intracranial GCTs include surgery, chemotherapy, and radiation therapy (RT). Surgical intervention may be utilized for establishing the histopathological diagnosis and management of symptoms due to tumor compression. Nevertheless, extensive surgical resection may not be feasible due to the critical location of some tumors in the vicinity of several vital structures. RT plays a major role in the management of patients with primary intracranial GCTs.

RT volumes for primary intracranial GCTs may include focal treatment volumes, whole ventricle irradiation, whole brain irradiation, or irradiation of the entire neuroaxis. RT doses and volumes for management of primary intracranial GCTs have been an area of active research over the years [4-10].

Optimal sparing of normal tissues has been a pertinent goal of RT in recent years to achieve an improved toxicity profile for patients with primary intracranial GCTs. In this context, contemporary RT strategies such as Image Guided Radiation Therapy (IGRT), Intensity Modulated Radiation Therapy (IMRT), precision particle threapy, and radiosurgery in the forms of Stereotactic Radiosurgery (SRS) and Hypofractionated Stereotactic Radiation Therapy (HFSRT) have been utilized to improve the therapeutic ratio. Favorable overall survival rates achieved with advanced technologies and effective treatments have rendered quality-of-life a critical aspect of patient management. Improved sparing of critical organs by use of less extensive RT volumes and lower doses has been investigated for avoiding excessive morbidity of treatment $[11,12]$. 
Radiosurgical applications are used to treat several tumors in the central nervous system and other locations [1328]. Due to the high and ablative doses delivered in a single fraction or a few fractions with radiosurgery, small lesions are best suited for radiosurgical management with improved precision in target localization. The rationale is delivery of high doses to well-defined targets to achieve improved local control with optimal normal tissue sparing. In the context of primary intracranial GCT management, radiosurgery may be considered for salvage treatment of recurrent lesions given the limited tolerance of surrounding critical organs due to upfront radiotherapeutic management [29,30]. Although not widely utilized, upfront radiosurgery has also been used for management of primary intracranial GCTs [31].

Target volume definition is a critical aspect of radiosurgery since smaller volumes are treated with high dose per fraction. Traditionally, treatment planning for radiosurgery is based on Computed Tomography (CT). Herein, we assess intracranial GCT treatment volume determination and provide a concise review of relevant literature.

\section{METHODS}

Definition of intracranial GCT treatment volumes based on incorporation of Magnetic Resonance Imaging (MRI) was comparatively assessed in our study. Reference treatment volume was defined after thorough assessment and collaboration of the board certified radiation oncologists. Treatment by radiosurgical management was concluded after comprehensively evaluating patient, tumor and treatment related factors by a multidisciplinary team of experts from neuroradiology, oncology, and neurosurgery. Computed Tomography (CT)-simulation was done and then target volumes with surrounding normal tissues delineated. Determination of radiosurgery target volume was based on solely CT or fusion of CT and MRI. Comparative evaluation of treatment volume determination was performed. Ground truth target volume definition has been accomplished by the board certified treating physicians after thorough collaboration and consensus. Synergy (Elekta, UK) Linear Accelerator (LINAC) has been utilized for radiosurgery treatment delivery. Image Guided Radiation Therapy (IGRT) techniques such as kV-CBCT (kilovoltage Cone Beam CT) and XVI (X-ray Volumetric Imaging, Elekta, UK) have been routinely utilized for verification of treatment.

\section{RESULTS AND DISCUSSION}

Definition of treatment volume for radiosurgery was assessed. Ground truth target volume defined after thorough evaluation and collaboration of the board certified radiation oncologists was similar with treatment volume definition based on fused CT and MRI.

A single 360-degree arc, double 360-degree arcs, or five 180-degree arcs have been selected for radiosurgery planning to achieve optimal institutional planning objectives. Windows and levels of the planning CT-simulation images have been adjusted to achieve improved visualization of target and critical structures. Coronal and sagittal images have been used in addition to axial images to improve precision in target and critical structure delineation. Target coverage and normal tissue sparing has been optimized further by utilizing the Arc Modulation Optimization Algorithm (AMOA). Figure 1 shows axial planning CT image. Axial MRI of intracranial GCT is demonstrated on Figure 2. 


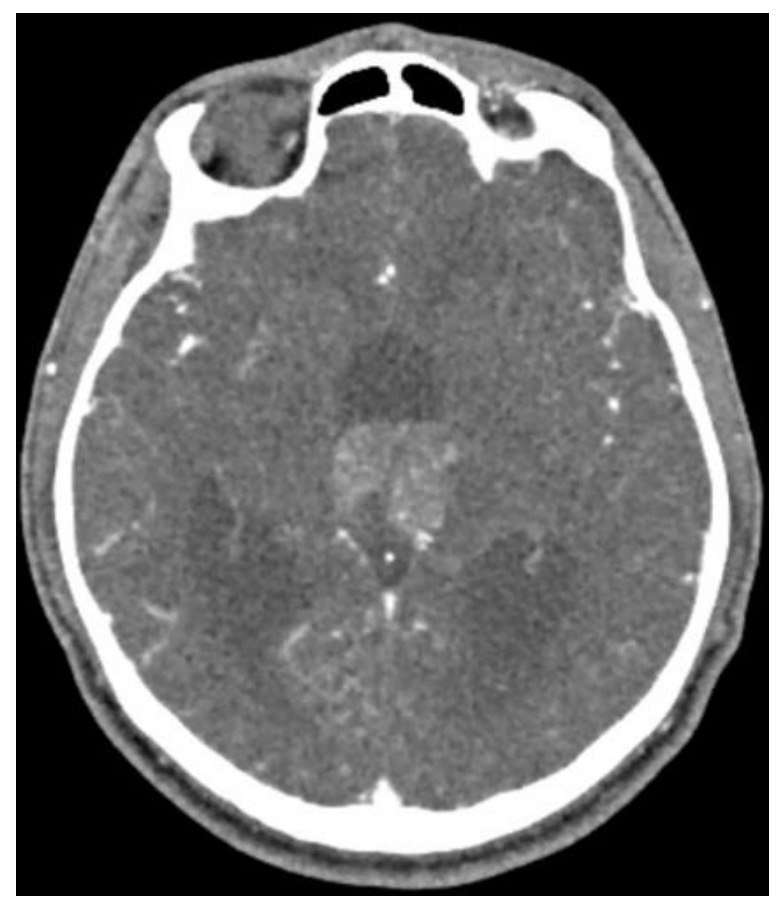

Figure 1- Intracranial GCT shown on CT

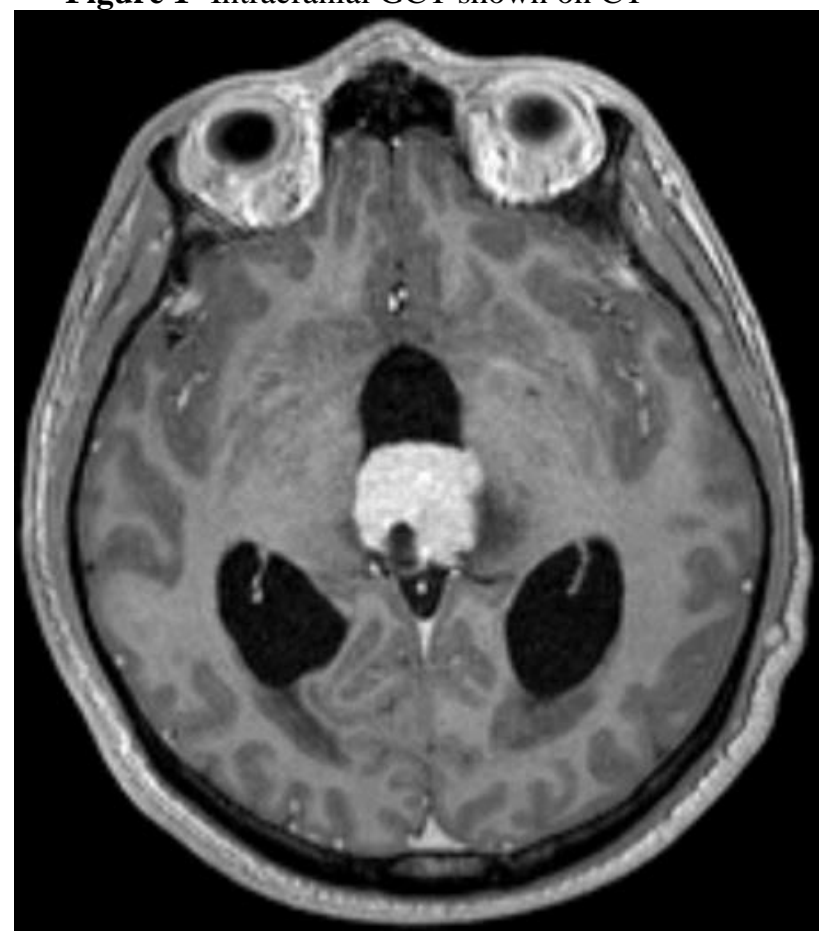

Figure 2- Intracranial GCT shown on MRI

RT serves as a major component of intracranial GCT management. Recent years have witnessed unprecedented advances in the discipline of radiation oncology including Image Guided Radiation Therapy (IGRT), Adaptive Radiation Therapy (ART), Intensity Modulated Radiation Therapy (IMRT), Breathing Adapted Radiation Therapy (BART), and stereotactic irradiation with Stereotactic Radiosurgery (SRS), Hypofractionated Stereotactic Radiation Therapy (HFSRT), and Stereotactic Body Radiation Therapy (SBRT) [32-39]. In the context of intracranial GCT management, irradiation with less extensive treatment portals and lower doses has been investigated for improved normal tissue sparing and quality of life. Given the relatively long survival of patients with intracranial GCTs, treatment related morbidity has been considered as a pertinent endpoint. Contemporary technologies for RT delivery such as SRS and HFSRT provide focused irradiation of well defined targets with optimal sparing of surrounding critical structures. SRS and HFSRT has been utilized for management of intracranial GCT as well as several other intracranial benign and malignant tumors [29-31]. Primary advantage of radiosurgical management is the capability of delivering high and 
effective doses with negligible normal tissue exposure. However, target definition comprises a very critical part of radiosurgery since inaccurate target contouring may result in either geographical miss or excessive exposure of surrounding normal tissues resulting in severe treatment related toxicity. In this context, multimodality imaging may add to the accuracy of target definition for radiosurgery of intracranial GCTs. Indeed several other studies have demonstrated refined treatment volume determination by including MRI to the process of target determination [39-51].

Our study adds to the growing body of evidence by reporting improved target definition by incorporation of MRI into radiosurgery treatment planning for intracranial GCTs. Since MRI may provide additional imaging data which may be judiciously incorporated for improved target determination, precise localization of intracranial GCTs may be achieved by complementing the planning CT images with fusion of MRI. Nevertheless, further imaging data may be required for improved accuracy in target definition for intracranial GCT radiosurgery to achieve optimal treatment outcomes.

\section{CONCLUSIONS}

In conclusion, radiosurgery treatment planning for intracranial GCTs may be improved by incorporation of MRI into target definition process. Clearly, further studies are warranted to draw firm conclusions on optimal target definition for intracranial GCT radiosurgery.

\section{LIMITATIONS}

Although our study focuses on target definition for intracanial GCT radiosurgery which is poorly addressed in the literature, further supporting data from future studies may be needed for establishing a consensus for precise target definition.

\section{ACKNOWLEDGEMENTS}

The authors have no acknowledgements and no conflicts of interest.

\section{REFERENCES}

[1] Ostrom QT, Gittleman H, Truitt G, Boscia A, Kruchko C, Barnholtz-Sloan JS. CBTRUS Statistical Report: Primary Brain and Other Central Nervous System Tumors Diagnosed in the United States in 2011-2015. Neuro Oncol. vol. 20, no. (suppl_4), pp. iv1-iv86, 2018.

[2] Wong TT, Ho DM, Chang KP, Yen SH, Guo WY, Chang FC, Liang ML, Pan HC, Chung WY. Primary pediatric brain tumors: statistics of Taipei VGH, Taiwan (1975-2004). Cancer. vol. 104, no. 10, pp. 2156-2167, 2005.

[3] Lee CH, Jung KW, Yoo H, Park S, Lee SH. Epidemiology of primary brain and central nervous system tumors in Korea. J Korean Neurosurg Soc. vol. 48, no. 2, pp. 145-152, 2010.

[4] Hardenbergh PH, Golden J, Billet A, Scott RM, Shrieve DC, Silver B, Loeffler JS, Tarbell NJ. Intracranial germinoma: the case for lower dose radiation therapy. Int J Radiat Oncol Biol Phys. vol. 39, no. 2, pp. 419-426, 1997.

[5] Nguyen QN, Chang EL, Allen PK, Maor MH, Ater JL, Mahajan A, Wolff JE, Weinberg JS, Woo SY. Focal and craniospinal irradiation for patients with intracranial germinoma and patterns of failure. Cancer. vol. 107, no. 9, pp. 22282236, 2006.

[6] Cho J, Choi JU, Kim DS, Suh CO. Low-dose craniospinal irradiation as a definitive treatment for intracranial germinoma. Radiother Oncol. vol 91, no. 1, pp. 75-79, 2009.

[7] Chen YW, Huang PI, Ho DM, Hu YW, Chang KP, Chiou SH, Guo WY, Chang FC, Liang ML, Lee YY, Chen HH, Hsu TR, Lin SC, Wong TT, Yen SH. Change in treatment strategy for intracranial germinoma: long-term follow-up experience at a single institute. Cancer. vol. 118, no. 10, pp. 2752-2762, 2012.

[8] Kim

JY, Park

J.

Understanding the Treatment Strategies of Intracranial Germ Cell Tumors: Focusing on Radiotherapy. J Korean Neurosurg Soc. vol. 57, no. 5, pp. 315-322, 2015.

[9] Rogers SJ, Mosleh-Shirazi MA, Saran FH.

Radiotherapy of localised intracranial germinoma: time to sever historical ties? Lancet Oncol. vol. 6, no. 7, pp. 509-519, 2005.

[10] Jensen AW, Laack NN, Buckner JC, Schomberg PJ, Wetmore CJ, Brown PD. Long-term follow-up of dose-adapted and reduced-field radiotherapy with or without chemotherapy for central nervous system germinoma. Int $\mathrm{J}$ Radiat Oncol Biol Phys. vol. 77, no. 5, pp. 1449-1456, 2010.

[11] Bamberg M, Kortmann RD, Calaminus G, Becker G, Meisner C, Harms D, Göbel U. Radiation therapy for intracranial germinoma: results of the German cooperative prospective trials MAKEI 83/86/89. J Clin Oncol. vol. 17, no. 8, pp. 2585-2892, 1999.

[12] Kortmann R, Worch J, Nicholson JC, Alapetite C, Garrè ML, Patte C, Ricardi U, Saran F, Frappaz D. SIOP CNS GCT 96: final report of outcome of

a prospective, multinational nonrandomized trial for children and adults with intracranial germinoma, comparing cranios pinal irradiation alone with chemotherapy followed by focal primary site irradiation for patients with localized disease.

Neuro Oncol. vol. 15, no. 6, pp. 788-796, 2013.

Asian Online Journals (www.ajouronline.com) 
[13] Dincoglan F, Beyzadeoglu M, Sager O, Uysal B, Demiral S, Gamsiz H, Dirican B. Evaluation of linear acceleratorbased stereotactic radiosurgery in the management of meningiomas: a single center experience. J BUON, vol. 18, no. 3, pp. 717-722, 2013.

[14] Sager O, Beyzadeoglu M, Dincoglan F, Uysal B, Gamsiz H, Demiral S, Oysul K, Dirican B, Sirin S. Evaluation of linear accelerator (LINAC)-based stereotactic radiosurgery (SRS) for cerebral cavernous malformations: a 15-year single-center experience. Ann Saudi Med, vol. 34, no. 1, pp. 54-58, 2014.

[15] Sager O, Beyzadeoglu M, Dincoglan F, Gamsiz H, Demiral S, Uysal B, Oysul K, Dirican B, Sirin S. Evaluation of linear accelerator-based stereotactic radiosurgery in the management of glomus jugulare tumors. Tumori, vol. 100, no. 2, pp. 184-188, 2014.

[16] Gamsiz H, Beyzadeoglu M, Sager O, Dincoglan F, Demiral S, Uysal B, Surenkok S, Oysul K, Dirican B. Management of pulmonary oligometastases by stereotactic body radiotherapy. Tumori, vol. 100, no. 2, pp. 179-183, 2014.

[17] Dincoglan F, Sager O, Gamsiz H, Uysal B, Demiral S, Oysul K, Sirin S, Caglan A, Beyzadeoglu M. Management of patients with $\geq 4$ brain metastases using stereotactic radiosurgery boost after whole brain irradiation. Tumori, vol. 100, no. 3, pp. 302-306, 2014.

[18] Demiral S, Beyzadeoglu M, Sager O, Dincoglan F, Gamsiz H, Uysal B, Oysul K, Gundem E, Dirican B, Sirin S. Evaluation of Linear Accelerator (Linac)-Based Stereotactic Radiosurgery (Srs) for the Treatment of Craniopharyngiomas. Int J Hematol Oncol, vol. 24, no. 2, pp. 123-129, 2014.

[19] Gamsiz H, Beyzadeoglu M, Sager O, Demiral S, Dincoglan F, Uysal $\quad$ B, Onal E, Dirican B. Evaluation of stereotactic body radiation therapy in the management of adrenal metastases from non-small cell lung cancer. Tumori, vol. 101, no. 1, pp. 98-103, 2015.

[20] Sager O, Dincoglan F, Beyzadeoglu M. Stereotactic radiosurgery of glomus jugulare tumors: current concepts, recent advances and future perspectives. CNS Oncol, vol. 4, no. 2, pp. 105-114, 2015

[21] Dincoglan F, Beyzadeoglu M, Sager O, Demiral S, Gamsiz H, Uysal B, Ebruli C, Akin M, Oysul K, Sirin S, Dirican B. Management of patients with recurrent glioblastoma using hypofractionated stereotactic radiotherapy. Tumori, vol. 101, no. 2, pp. 179-184, 2015.

[22] Demiral S, Dincoglan F, Sager O, Gamsiz H, Uysal B, Gundem E, Elcim Y, Dirican B, Beyzadeoglu M. Hypofractionated stereotactic radiotherapy (HFSRT) for who grade I anterior clinoid meningiomas (ACM). Jpn J Radiol, vol. 34, no. 11, pp. 730-737, 2016.

[23] Dincoglan F, Sager O, Demiral S, Uysal B, Gamsiz H, Dirican B, Beyzadeoglu M. Radiosurgery for recurrent glioblastoma: a review article. Neurol Disord Therap, vol.1, no. 4, pp. 1-5, 2017.

[24] Demiral S, Dincoglan F, Sager O, Uysal B, Gamsiz H, Ozcan F, Dirican B, Beyzadeoglu M. Contemporary Management of Meningiomas with Radiosurgery. Int J Radiol Imaging Technol, vol. 4, pp. 041, 2018.

[25] Dincoglan F, Sager O, Demiral S, Uysal B, Gamsiz H, Dirican B, Beyzadeoglu M. Radiosurgery for recurrent glioblastoma: A review article. Neurol Disord Therap. vol. 1, pp. 1-5.

[26] Dincoglan F, Sager O, Uysal B, Demiral S, Gamsiz H, Gündem E, Elcim Y, Dirican B, Beyzadeoglu M. Evaluatıon of hypofractionated stereotactic radiotherapy (HFSRT) to the resection cavity after surgical resection of brain metastases: A single center experience. Indian J Cancer. vol. 56, no. 3, pp. 202-206, 2019.

[27] Dincoglan F, Sager O, Demiral S, Gamsiz H, Uysal B, Onal E, Ekmen A, Dirican B, Beyzadeoglu M. Fractionated stereotactic radiosurgery for locally recurrent brain metastases after failed stereotactic radiosurgery. Indian J Cancer. vol. 56, no. 2, pp. 151-156, 2019.

[28] Dincoglan F, Beyzadeoglu M, Sager O, Demiral S, Uysal B, Gamsiz H, Colak A, Ozcan F, Dirican B. A Concise Review of Irradiation for Temporal Bone Chemodectomas (TBC). Arch Otolaryngol Rhinol. vol 6, no. 2, pp. 016-020, 2020.

[29] Hu YW, Huang PI, Wong TT, Ho DM, Chang KP, Guo WY, Chang FC, Shiau CY, Liang ML, Lee YY, Chen $\mathrm{HH}$, Yen SH, Chen YW. Salvage treatment for recurrent intracranial germinoma after reduced-volume radiotherapy: a single-institution experience and review of the literature. Int J Radiat Oncol Biol Phys. vol. 84, no. 3, pp. 639-647, 2012. [30] Wong K, Opimo AB, Olch AJ, All S, Waxer JF, Clark D, Cheng J, Chlebik A, Erdreich-Epstein A, Krieger MD, Tamrazi B, Dhall G, Finlay JL, Chang EL. Re-irradiation of Recurrent Pineal Germ Cell Tumors with Radiosurgery: Report of Two Cases and Review of Literature. Cureus. vol. 8, no. 4, pp. e585, 2016.

[31] Yang QY, Guo CC, Deng ML, Wang J, Wang J, Lin FH, Zhang J, Jiang XB, Mou YG, Chen ZP. Treatment of primary intracranial germ cell tumors: Single center experience with 42 clinically diagnosed cases. Oncotarget. vol. 7 , no. 37, pp. 60665-60675, 2016.

[32] Sager O, Beyzadeoglu M, Dincoglan F, Oysul K, Kahya YE, Gamsiz H, Uysal B, Demiral S, Dirican B, Surenkok S. Evaluation of active breathing control-moderate deep inspiration breath-hold in definitive non-small cell lung cancer radiotherapy. Neoplasma. Vol. 59, no. 3, pp. 333-340, 2012.

[33] Dincoglan F, Beyzadeoglu M, Sager O, Oysul K, Kahya YE, Gamsiz H, Uysal B, Demiral S, Dirican B, Surenkok S. Dosimetric evaluation of critical organs at risk in mastectomized left-sided breast cancer radiotherapy using breath-hold technique. Tumori. vol. 99, no. 1, pp. 76-82, 2013. 
[34] Uysal B, Beyzadeoğlu M, Sager O, Dinçoğlan F, Demiral S, Gamsız H, Sürenkök S, Oysul K. Dosimetric evaluation of intensity modulated radiotherapy and 4-field 3-d conformal radiotherapy in prostate cancer treatment. Balkan Med J. vol. 30, no. 1, pp. 54-57, 2013.

[35] Sager O, Beyzadeoglu M, Dincoglan F, Demiral S, Uysal B, Gamsiz H, Akin M, Gundem E, Dirican B. Adaptive splenic radiotherapy for symptomatic splenomegaly management in myeloproliferative disorders. Tumori. vol. 101 , no. 1, pp. 84-90, 2015.

[36] Sager O, Dincoglan F, Uysal B, Demiral S, Gamsiz H, Beyzadeoglu M. Splenic Irradiation: A Concise Review of the Literature. J App Hem Bl Tran. Vol. 1, no. 1, pp. 101, 2017.

[37] Sager O, Dincoglan F, Uysal B, Demiral S, Gamsiz H, Elcim Y, Gundem E, Dirican B, Beyzadeoglu M. Evaluation of adaptive radiotherapy (ART) by use of replanning the tumor bed boost with repeated computed tomography (CT) simulation after whole breast irradiation (WBI) for breast cancer patients having clinically evident seroma. Jpn J Radiol. vol. 36, no. 6, pp. 401-406, 2018.

[38] Sager O, Dincoglan F, Demiral S, Uysal B, Gamsiz H, Ozcan F, Colak O, Elcim Y, Dirican B, Beyzadeoglu M. Breathing adapted radiation therapy for leukemia relapse in the breast: A case report. World J Clin Oncol. vol. 10, no. 11, pp. 369-374, 2019.

[39] Demiral S, Sager O, Dincoglan F, Beyzadeoglu M. Assessment of Computed Tomography (CT) And Magnetic Resonance Imaging (MRI) Based Radiosurgery Treatment Planning for Pituitary Adenomas. Canc Therapy \& Oncol Int J. vol 13, no. 2, pp. 555857, 2019.

[40] Beyzadeoglu M, Sager O, Dincoglan F, Demiral S. Evaluation of Target Definition for Stereotactic Reirradiation of Recurrent Glioblastoma. Arch Can Res. vol 7, no. 1, pp. 3, 2019.

[41] Sager O, Dincoglan F, Demiral S, Beyzadeoglu M. Evaluation of Radiosurgery Target Volume Determination for Meningiomas Based on Computed Tomography (CT) And Magnetic Resonance Imaging (MRI) Cancer Sci Res Open Access. vol 5, no. 2, pp. 1-4, 2019.

[42] Dincoglan F, Sager O, Demiral S, Beyzadeoglu M. Multimodality Imaging for Radiosurgical Management of Arteriovenous Malformations. Asian Journal of Pharmacy, Nursing and Medical Sciences. vol. 7, no. 1, pp. 7-12, 2019.

[43] Demiral S, Sager O, Dincoglan F, Beyzadeoglu M. Assessment of target definition based on Multimodality imaging for radiosurgical Management of glomus jugulare tumors (GJTs). Canc Therapy \& Oncol Int J. vol. 15, no. 2, pp. 555909, 2019.

[44] Sager O, Dincoglan F, Demiral S, Gamsiz H, Uysal B, Dirican B, Beyzadeoglu M. Utility of Magnetic Resonance Imaging (Imaging) in Target Volume Definition for Radiosurgery of Acoustic Neuromas. Int J Cancer Clin Res. vol. 6, no. 3, pp. 119, 2019.

[45] Sager O, Dincoglan F, Demiral S, Gamsiz H, Uysal B, Ozcan F, Colak O, Dirican B, Beyzadeoglu M. Evaluation of the Impact of Magnetic Resonance Imaging (MRI) on Gross Tumor Volume (GTV) Definition for Radiation Treatment Planning (RTP) of Inoperable High Grade Gliomas (HGGs). Concepts in Magnetic Resonance Part A. vol 2019, pp. 1-7, Article ID 4282754, 2019.

[46] Demiral S, Sager O, Dincoglan F, Uysal B, Gamsiz H, Dirican B, Beyzadeoglu M. Evaluation of Target Volume Determination for Single Session Stereotactic Radiosurgery (SRS) of Brain Metastases. Canc Therapy \& Oncol Int J. vol. 12, no. 5, pp. 555848, 2018.

[47] Sager O, Demiral S, Dincoglan F, Beyzadeoglu M. Target Volume Definition for Stereotactic Radiosurgery (SRS) Of Cerebral Cavernous Malformations (CCMs). Canc Therapy \& Oncol Int J. vol. 15, no. 4, pp. 555917, 2020.

[48] Dincoglan F, Demiral S, Sager O, Beyzadeoglu M. Utility of Multimodality Imaging Based Target Volume Definition for Radiosurgery of Trigeminal Neuralgia: An Original Article. Biomed J Sci \& Tech Res. vol. 26, no. 2, pp. 19728-19732, 2020.

[49] Sager O, Dincoglan F, Demiral S, Beyzadeoglu M. Radiosurgery Treatment Volume Determination for Brain Lymphomas with and without Incorporation of Multimodality Imaging. Journal of Medical Pharmaceutical and Allied Sciences. vol. 9, no. 1, pp. 2398-2404, 2020.

[50] Beyzadeoglu M, Dincoglan F, Demiral S, Sager O. Target Volume Determination for Precise Radiation Therapy (RT) of Central Neurocytoma: An Original Article. International Journal of Research Studies in Medical and Health Sciences. vol. 5, no. 3, pp. 29-34, 2020.

[51] Demiral S, Beyzadeoglu M, Dincoglan F, Sager O. Assessment of Target Volume Definition for Radiosurgery of Atypical Meningiomas with Multimodality Imaging. Journal of Hematology and Oncology Research. vol. 3, no. 4, pp. 14-21, 2020. 